\title{
Trademark Transactions in EU Law - Refining the Approach to Selective Distribution Networks and National Unfair Competition Law
}

\author{
Martin Senftleben*
}

Table of Contents

A. Introduction

B. Overview of Harmonized EU Rules

1. Community Trade Mark Regulation

2. Trade Mark Directive

3. Reform Plans

C. Selective Distribution Networks

1. The Case Copad/Dior

2. Expansion of the Concept of Product Quality

3. Impact on Exhaustion of Rights

4. Open Questions

5. Rights Against the Licensee

6. Rights Against Outside Traders

7. A More Nuanced Approach

D. Interplay With National Unfair Competition Law

1. The Case Martin Y Paz/Depuydt

2. Mantra of Complete Harmonization

3. Function Theory Unsatisfactory

4. No Pre-Emption of National Doctrines

E. Conclusion

\section{A. Introduction}

Harmonized European Union (EU) trademark law contains rules on trademarks as objects of property, including transfers and licenses, in Articles 16 to 24 of the Community Trade Mark Regulation (CTMR) ${ }^{1}$ and a provision on licensing in Article 8 of the Trade Mark Directive (TMD). ${ }^{2}$ The rudimentary nature of this set of EU rules clearly comes to the fore in Article 16(1) of the CTMR: unless the CTMR provides harmonized norms, questions concerning Community Trade Marks (CTMs) as objects of property must be answered - for the whole EU territory - on the basis of the national law of a single EU Member State. The applicable national law is to be determined in accordance with the rules on points of attachment given in Article 16 of the CTMR. The seat or domicile of the trademark proprietor serves as the

\footnotetext{
* Professor of Intellectual Property and Director, Kooijmans Institute for Law and Governance, VU University Amsterdam; Of Counsel, Bird \& Bird, The Hague.

${ }^{1}$ Council Regulation No 207/2009 of 26 February 2009 on the Community trademark (codified version), 2009 O.J. (L 78) 1 (EC) [hereinafter CTMR].

${ }^{2}$ Directive 2008/95, of the European Parliament and of the Council of 22 October 2008 to approximate the laws of the Member States relating to trademarks (codified version), 2008 O.J. (L 299) 25 [hereinafter TMD].
} 
primary point of attachment. ${ }^{3}$ An establishment can be used as an alternative. ${ }^{4}$ As the EU trademark office - the Office for Harmonization in the Internal Market (OHIM) - has its seat in Alicante, Spain, the national law of Spain applies in default of a seat, domicile or establishment. ${ }^{5}$

The regulation of trademark transactions in the EU thus relies on a harmonious interplay of harmonized EU law and individual national legislation. This configuration of the system places a particular responsibility on the Court of Justice of the European Union (CJEU). When interpreting harmonized EU rules, the CJEU ought to consider the impact of its decision on the proper functioning of national law. An overambitious approach seeking to maximize the harmonizing effect of the rudimentary set of EU norms will almost inevitably lead to unsatisfactory results. After a short overview of EU "objects of property" rules and present amendment proposals (following Section B of this Chapter), two decisions of the CJEU will be brought into focus to illustrate this point. The decision in Copad/Dior gives rise to concerns about harmonized rules in the TMD becoming a "straightjacket" with insufficient breathing space for the reconciliation of licensor, licensee and third party interests (discussed in Section C of this Chapter). The case of Martin Y Paz/Depuydt sheds light on the potential corrosive effect of harmonized EU rules on national unfair competition law (discussed in Section D of this Chapter). The analysis shows the structural deficiencies of the current EU system and the need for additional fine-tuning based on both EU and national norms (concluding Section E of this Chapter).

\section{B. Overview of Harmonized EU Rules}

\section{Community Trade Mark Regulation}

Article 16 of the CTMR sets forth the aforementioned rules on the interplay between harmonized EU norms and the application of the national law of a single Member State. ${ }^{6}$ In line with Articles 20(2) and 23(3) of the CTMR, the points of attachment specified in this context (i.e. seat/domicile/establishment) also serve as a basis for determining the national courts and authorities for levy of execution in respect of a CTM and the law governing effects vis-à-vis third parties. ${ }^{7}$ Jurisdiction for involving a Community trade mark in insolvency proceedings depends on the question in which Member State the debtor has his main interests or - in case of an insurance undertaking or a credit institution - in which Member State that undertaking or institution has been authorized. ${ }^{8}$

Transfers are regulated in Articles 17 and 18 of the CTMR while Article 22 of the CTMR deals with licensing. The CTMR provides for whole or partial transfers independent of the

\footnotetext{
${ }^{3}$ CTMR, supra note 1 , at art. 16 .

${ }^{4} I d$.

${ }^{5} I d$. at arts. 16(1)(a), (b) and (2). Cf. TOBias COHEN JEHORAM, CONSTANT VAN NisPen, TONy HuydeCoper, EUROPEAN TRADEMARK LAW 534-535. (2010).

${ }^{6}$ CTMR, supra note 1 , at art. 16 .

${ }^{7} I d$., at arts. 20(2) and 23(3).

${ }^{8} I d$., at art. 21(1).
} 
underlying business or undertaking. ${ }^{9}$ The underlying concept of "transfer" includes assignment, legal succession (for example, in cases of heritage or merger), and changes of the legal structure resulting in the creation of a new legal person. ${ }^{10} \mathrm{~A}$ sale of the whole of an undertaking entails the transfer of CTMs unless there is agreement to the contrary or the circumstances surrounding the transfer dictate otherwise. ${ }^{11}$ In order to be valid, a transfer requires written form and the signature of the parties involved. ${ }^{12}$

For the successor in title to be able to invoke the rights in the CTM, the transfer must be registered. ${ }^{13}$ OHIM will refuse to register a transfer if, as a result of the transaction, the CTM is likely to mislead the public with regard to the nature, quality or geographical origin of the goods or services for which it is registered. ${ }^{14}$ For a transfer to be deemed misleading in cases of a trademark corresponding to the name of a natural person, it is not sufficient that the successor continues to use the trademark even though the natural person has left the company. ${ }^{15}$ As long as the characteristics and the quality of the goods or services remain guaranteed by the trademark owner, the link established by the trademark is considered correct unless the trademark owner has an intention to make consumers believe that the natural person is still involved. ${ }^{16}$ The successor can also overcome the obstacle of a misleading transfer by limiting the registration to goods or services in respect of which this misleading effect does not arise. ${ }^{17}$ In line with Article 6septies of the Paris Convention, Article 18 of the CTMR provides for the assignment of a CTM to the rightful proprietor in case an agent or representative registered the mark in his own name without proper authorization or justification. ${ }^{18}$

Given the unitary character of the CTM which, in line with Article 1 of the CTMR, leads to an equal effect throughout the EU, Article 17(1) of the CTMR only mentions the option of a

\footnotetext{
9 JEHORAM, VAN NISPEN \& MUYDECOPER, supra note 5, at 536. For an overview of the different national traditions in the EU discussing the possibility and preconditions of independent transfers, see Annette Kur, Die gemeinschaftiche Markenbenutzung - Markenlizenzen und verwandte Tatbestände,,GEWERBLICHER RECHTSSCHUTZ UND URHEBERRECHT INTERNATIONAL, 1, 2-4 (1990).

${ }^{10}$ In case of the change of the legal structure, applicable national corporate law may provide for the predecessor and successor company to be considered the same legal entity. See Andreas Renck, Community Trade marks as Objects of Property, in CONCISE EUROPEAN TRADEMARK AND DESIGN LAW, 90, 92-93 (Charles Gielen \& Verena von Bomhard eds., 2011) (mentioning German law on the transformation of legal entities as an example).

${ }^{11}$ CTMR, supra note 1 , at art. 17(2).

12 Id. at art. 17(3). This requirement of a transfer in written form does not exist in all national laws of EU Member States. Some national systems, such as the German system, are more flexible and acknowledge contracts which are not concluded in writing as well. See the analysis conducted by ROLAND KNAAK, ANNETTE Kur, \& AlEXANDER VON MÜHLENDAhl, MAX Planck Institute For InTEllectual Property AND COMPetition Law, Study on the Overall Functioning of the European Trade Mark System 227, 9 2.19 (2011), available at $\mathrm{http} / /$ ec.europa.eu/internal_market/indprop/tm/index_en.htm, para.

${ }^{13} I d$. at art. 17(5). For the evidence of the transfer necessary for registration, see Renck, supra note 10, at 94-95.

${ }^{14}$ CTMR, supra note 1 , at art. 17(4).

${ }^{15}$ Case C-259/04, Elizabeth Florence Emanuel v.Continental Shelf 128, 2006 E.C.R. I-3110.

${ }^{16}$ Id. at 9 49-50. But see Pier Luigi Roncaglia \& Giulio Enrico Sironi, Trademark Functions and Protected Interests in the Decisions of the European Court of Justice, 101 TRADEMARK REP. 147, 172-173 (2011) (arguing that by focusing on material characteristics of the designer garments at issue, the CJEU neglected other features, such as style, which are central to the purchasing decision of consumers).

${ }^{17}$ CTMR, supra note 1, at art. 17(4) and 17(5).

${ }^{18} I d$. at art. 18 .
} 
partial transfer in respect of some of the goods or services. ${ }^{19}$ A territorial restriction of the transfer of a CTM is invalid. ${ }^{20}$ Licenses concerning a CTM, by contrast, can also be given for only part of the EU. ${ }^{21}$ In general, the CJEU interprets the grant of a license to mean that:

$[\mathrm{T}]$ he proprietor of a trade mark confers on the licensee, within the limits set by the clauses of the licensing contract, the right to use that mark for the purposes falling within the area of the exclusive rights conferred by that mark, that is to say, the commercial use of that mark in a manner consistent with its functions, in particular the essential function of guaranteeing to consumers the origin of the goods or services concerned. ${ }^{22}$

In case of doubt about the nature of a contract concerning a trademark, the authorization "to use the trademark commercially in a manner consistent with its function" can play a decisive role. ${ }^{23}$ In the absence of an entitlement to use the trademark commercially to distinguish goods or services in the marketplace, a contract for the use of a trademark to obtain a registration of a corresponding domain name, for example, may be more akin to a contract for services than to a licensing agreement. ${ }^{24}$

Where a licensee contravenes a provision in the licensing agreement concerning the duration of the contract, the form of use, the scope of the goods or services, the territorial scope of the license or the quality of the goods or services, the trademark proprietor may invoke his trademark rights against the licensee. ${ }^{25}$ For bringing infringement proceedings, the licensee, in principle, requires consent from the trademark proprietor. However, the holder of an exclusive license may bring infringement proceedings if the trademark proprietor does not take action himself within an appropriate period after formal notice. ${ }^{26}$ The parties to a licensing agreement are free to depart from these default rules. In any case, however, the licensee is free to intervene in infringement proceedings brought by the CTM proprietor, to obtain compensation for damages which he suffered as a licensee. ${ }^{27}$ If a counterclaim for revocation or a declaration of invalidity is brought in a legal action to which the trademark proprietor is not already a party, he must be informed of this development and may be joined as a party to the action in accordance with the conditions set forth in the applicable national law. ${ }^{28}$

\footnotetext{
${ }^{19}$ As to particular questions that can arise in the context of transfers with regard to seniority claims based on earlier national marks that have not been surrendered or allowed to lapse, see Renck, supra note 10, at 93.

${ }^{20}$ JEHORAM, VAN NISPEN, \& HUYDECOPER, supra note 5, at 537.

${ }^{21}$ CTMR, supra note 1 , at art. 22(1).

${ }^{22}$ Case C-376/11, Pie Optiek SPRL v. Bureau Gevers SA and European Registry for Internet Domains ASBL, ECLI:EU:C:2012:502 (2012).

${ }^{23}$ Id. at $\uparrow \uparrow$ 50, 51 and 53.

${ }^{24} \mathrm{Id}$. at 52.

${ }^{25}$ CTMR, supra note 1 , at art. 22(2).

${ }^{26} \mathrm{Id}$. at art. 22(3).

${ }^{27} \mathrm{Id}$. at art. 22(4).

${ }^{28} \mathrm{Id}$. at art. 100(3)
} 
Article 19(1) of the CTMR establishes the principle that a CTM may be given as security and be the subject of rights in rem independently of the undertaking. ${ }^{29}$ Article 20(1) of the CTMR adds that a CTM, as already indicated, may be levied in execution. Unless a third party acquiring rights in a CTM had knowledge of a transfer, security interest, other right in rem or license, these legal acts will only have effect vis-à-vis third parties after they have been entered in the CTM register on request of one of the parties to the trademark transaction. ${ }^{30}$ As Article 23(1) of the CTMR refers to positive "knowledge" in this latter context, constructive or imputed knowledge are unlikely to suffice. A notice of the trademark transaction will thus normally be necessary to achieve third party effects in the absence of registration. ${ }^{31}$ However, these rules on effects vis-à-vis third parties do not apply when the trademark, or a right concerning the trademark, is acquired by way of transfer of the whole undertaking or by universal succession. ${ }^{32}$ Levy of execution (by request of one of the parties in accordance with Article 20(3) of the CTMR) and involvement in insolvency proceedings (on request of the competent national authority in accordance with Article 21(3) of the CTMR) may be entered in the CTM Register as well.

\section{Trade Mark Directive}

In contrast to this set of legal norms in the CTMR, the rules in the TMD are limited to two aspects found in Article 8 of the TMD ${ }^{33}$. On the one hand, the first paragraph of the provision clarifies that a trademark - in this case a national trademark in a Member State - may be licensed for some or all of the goods or services for which it is registered and for the whole or part of the Member State concerned. ${ }^{34}$ Article 8(2) of the TMD draws a parallel with Article 22(2) of the CTMR by making it clear that also in case of a national trademark, the trademark proprietor may invoke his trademark rights against a licensee breaching a provision in the licensing agreement regarding the duration of the contract, the form of use, the scope of the goods or services, the territorial scope of the license or the quality of the goods or services. ${ }^{35}$

\section{Reform Plans}

The rules of harmonized EU trademark law are presently under review. The European Commission's package for amending the trademark legislation in the EU (the proposed new Regulation (Draft CTMR) $)^{36}$ and Directive (Draft TMD) ${ }^{37}$ ) contains the proposal to

\footnotetext{
${ }^{29}$ For a discussion of different types of rights in rem, see JEHORAM, VAN NISPEN \& HUYDECOPER, supra note 5, at 539-540.

${ }^{30}$ CTMR, supra note 1, at arts. 17(5), 19(2), and 22(5).

${ }^{31}$ Renck, supra note 10, at 101; JEHORAM, VAN NISPEN \& HUYDECOPER, supra note 5, at 539.

${ }^{32}$ CTMR, supra note 1, at art. 23(2).

${ }^{33}$ TMD, supra note 2, at art. 8.

${ }^{34} \mathrm{Id}$. at art. $8(1)$.

${ }^{35} I d$. at art $8(2)$.

${ }^{36}$ Commission Proposal for a Regulation of the European Parliament and of the Council Amending Council Regulation (EC) No 207/2009 on the Community Trade Mark, COM (2013) 161 final, (Mar. 27, 2013) [hereinafter Draft CTMR].

${ }^{37}$ Commission Proposal for a Directive of the European Parliament and of the Council to Approximate the laws of the Member States Relating to Trade marks, COM (2013) 162 final (Mar. 27, 2013) [hereinafter Draft TMD].
} 
supplement Article 8(1) and (2) of the TMD with further provisions taken from the CTMR. ${ }^{38}$ This proposal is in line with recommendations made during the preparatory work for the new trademark legislation. The Study of the Max Planck Institute on the Overall Functioning of the European Trade Mark System - the main preparatory work carried out for the new legislation - arrived at the following conclusion:

The TMD should be complemented by a comprehensive body of rules addressing trade marks as objects of property. With the exception of rules regulating the third party effects of registration of legal transactions and the examination of transfer documents for risks of consumer deception, the rules to be introduced should follow those of the CTMR, so as to ensure coherence. $^{39}$

Against this background, the Commission's reform package seeks to include the rules on transfers known from the CTMR in the TMD. ${ }^{40}$ It supplements the existing licensing norms with the rules from the CTMR on possibilities for the licensee to bring infringement proceedings and intervene in proceedings initiated by the trademark proprietor. ${ }^{41}$ Moreover, the Commission proposes to lay down rules ensuring that national trademarks can, independently of the undertaking, be given as security and be the subject of rights in $\mathrm{rem}^{42}$, and that they can be levied in execution. ${ }^{43} \mathrm{With}$ regard to transfers, licenses, security interests, other rights in rem, involvement in insolvency proceedings and licenses, the proposed amendment would include the option of registration in the national trademark register.

In the further legislative process, however, it became apparent that the Council of the European Union rejected several aspects of this broadening of the rules on trademark transactions in the TMD, such as the requirement of written form in the case of transfers, the possibility of recording insolvency proceedings in the register, and the rules on the initiation of, and intervention in, infringement proceedings in the case of licenses. ${ }^{44}$ As the European Parliament also expressed doubts about provisions in the field of transfers, ${ }^{45}$ it remains to be seen which elements of the Commission proposal will finally make their way into the new TMD.

\footnotetext{
${ }^{38}$ For general comments on the proposed new legislation, see Rolf Sack, Kritische Anmerkungen zur Regelung der Markenverletzungen in den Kommissionsvorschlägen für eine Reform des europäischen Markenrechts, 7/2013 GEWERBLICHER RECHTSSCHUTZ UND URHEBERRECHT 657, (2013); Tobias Cohen Jehoram, Nieuw en verbeterd! Het Europees merkenrecht - Commissievoorstel doet 3 stappen vooruit, 1 achteruit, 12-09-2013 BERICHTEN INDUSTRIËLE EIGENDOM 198-205 (2013).

${ }^{39}$ See Roland KNAAK, ANNetTe KuR, \& AlEXANDER VON MÜHLENDAHL, supra note 12 , at 92.24 (2011). For a more detailed discussion of the individual rules that should be transposed into the TMD according to the Study, see id. ๆף 2.17-2.23.

${ }^{40}$ Draft TMD, supra note 37, at art. 22.

${ }^{41} I d$. at art. 26(3) and (4).

${ }^{42} I d$. at art. 23.

${ }^{43} \mathrm{Id}$. at art. 24.

44 Presidency Compromise Proposal, Council of the European Union, arts. 22-26 (18 July 2014) , Interinstitutional File 2013/0089 (COD), no. 11827/14 PI 96 CODEC 1621.

${ }^{45}$ Legislative Resolution on the Proposal for a Directive of the European Parliament and of the Council to Approximate the Laws of the Member States Relating to Trademarks (recast), EUR. PARL. Doc. (COM 0162) Amendments 37-39 (2014).
} 


\section{Selective Distribution Networks}

\section{The Case Copad/Dior}

On the basis of this overview of harmonized EU trademark transactions law and current amendment proposals, it becomes possible to explore specific problem areas in more detail. One of the controversial issues in the regulation of trademark transactions is the approach to selective distribution networks. To what extent should the trademark proprietor be able to invoke trademark rights to control the activities of licensees and further distribution of branded goods and services? In CJEU jurisprudence on trademark transactions, the issue of selective distribution networks featured prominently in Copad/Dior ${ }^{46}$ The case concerned a licensing agreement that Dior had concluded with Société industrielle lingerie (SIL) regarding the manufacture and distribution of luxury corsetry goods bearing the Dior trademark. Under this agreement, SIL was bound to refrain from sales to wholesalers, discount stores etc. in order not to endanger the reputation and prestige of the luxury trademark. Nonetheless, SIL sold goods bearing the Dior trademark to Copad, a company operating a discount store business, even though Dior had explicitly refused SIL's request to grant permission for these sales outside its selective distribution network. ${ }^{47}$

In the light of Article 8(2) of the TMD, this case raised the question whether SIL's breach of contractual obligations amounted to trademark infringement or merely gave rise to contractual liability. As explained above, Article 8(2) of the TMD provides that the trademark proprietor can invoke trademark rights against a licensee who contravenes a provision of the licensing agreement dealing with duration, the form in which the trademark may be used, the scope of the goods or services falling under the license, the territory in which the trademark may be affixed, or the quality of the goods or services offered by the licensee. Given this enumeration of relevant contractual provisions, the CJEU was asked to give guidance on whether Article $8(2)$ of the TMD covered the contractual obligation to refrain from sales to discount stores.

Answering this question, the CJEU first addressed the issue of whether the list of categories of contractual stipulations in Article 8(2) of the TMD was exhaustive or merely illustrative. Tersely noting that Article 8(2) of the TMD contained "no adverb, or an expression such as "especially" or "in particular", that would allow a finding that the list simply provides guidance", ${ }^{48}$ the Court arrived at the conclusion that it followed from the "very wording" that the list of contractual stipulations in Article 8(2) of the TMD was exhaustive. ${ }^{49}$ To support this conclusion, the Court made a comparison to the text of Article 7(2) of the TMD regulating the right of the trademark proprietor to oppose the further commercialisation of goods after the exhaustion of trademark rights. As Article 7(2) of the TMD contains the adverb "especially", the Court found that it had to be understood to offer an illustrative list of

\footnotetext{
${ }^{46}$ Case C-59/08, Copad SA v. Christian Dior Couture SA and Others, 2008 E.C.R. I-03421.

${ }^{4}$ Id. at $\uparrow \uparrow 7-10$.

${ }^{48} I d$. at 918.

${ }^{49} I d$. at $\uparrow 20$.
} 
relevant circumstances, whereas Article 8(2) of the TMD set forth a closed list. ${ }^{50}$ In other words, only a breach of contractual stipulations falling under one of the five categories listed in Article 8(2) of the TMD allows the invocation of trademark rights against a licensee.

\section{Expansion of the Concept of Product Quality}

Taking this finding as a starting point, the question arose whether the contractual obligation to refrain from sales to discount stores could be brought within the scope of one of the categories listed in Article 8(2) of the TMD. The Court surmounted this hurdle by stating with regard to the category of "the quality of the goods manufactured":

[T] he quality of luxury goods such as the ones at issue in the main proceedings is not just the result of their material characteristics, but also of the allure and prestigious image which bestows on them an aura of luxury. ${ }^{51}$

According to the Court, the "allure and prestigious image" thus forms part of the quality of luxury goods besides material characteristics. This holding offered the chance of including the ban on sales outside a selective distribution network in the concept of "quality" in the sense of Article 8(2)(e) TMD. While this solution may reflect modern marketing strategies in the luxury goods industries, ${ }^{52}$ it is doubtful whether this alignment of Article $8(2)$ of the TMD with luxury brand owners' interests rests on a proper policy basis. To this day, the justification for protecting brand goodwill is an unresolved question of trademark law. ${ }^{53}$ Against this background, it becomes apparent that Copad/Dior took the protection of brand

\footnotetext{
${ }^{50}$ Id. at 19.

${ }^{51}$ Id. at 924.

${ }^{52}$ Cf. Agnieszka Machnicka, The Perfume Industry and Intellectual Property Law in the Jurisprudence of the Court of Justice of the European Union and of National Courts, 43 INT'L REV. OF InTELL. Prop. \& COMP. L. 123, 141-43 (2012) (describing the strategies applied by the luxury perfume industry).

${ }^{53}$ For a detailed analysis of potential justifications, see also WOLFGANG SAKULIN, TRADEMARK PROTECTION AND FREEDOM OF EXPRESSION - AN INQUIRY INTO THE CONFLICT BETWEEN TRADEMARK RIGHTS AND FREEDOM OF EXPRESSION UNDER EUROPEAN LAW, 35-67 (2010) (casting doubt upon the justificatory basis of protection against dilution). Proponents of brand image protection in the framework of trademark law particularly point to the effort and financial expenses made by the brand owner. For instance, see Andrew Griffiths, Quality in European Trademark Law, 11 Nw, J. TECH. \& INTELL. PROP. 621, 635-637 (2013); Andreas Breitschaft, Intel, Adidas \& Co - Is the Jurisprudence of the European Court of Justice on Dilution Law in Compliance with the Underlying Rationales and Fit for the Future? 30 EUR. InTELL. Prop. REV. 497, 499 (2009). Considering the costs for society involved in the grant of brand image protection - in particular restrictions of freedom of expression and freedom of competition - this fact alone, however, can hardly be deemed sufficient for the grant of broad exclusive rights. See Dominic Scott, A. Oliver, and Miguel Ley-Pineda, Trademarks as Property: a Philosophical Perspective, in TRADEMARKS AND BRANDS - AN INTERDISCIPLINARY CRITIQUE 298, 296-297 (Lionel Bently, Jennifer Davis, \& Jane C. Ginsburg eds.) and Martin R.F. Senftleben, The Trademark Tower of Babel - Dilution Concepts in International, US and EC Law, 40 INT'L REV. OF INTELL. Prop. \& COMP. L. 45, 5961 (2009) (considering product differentiation, facilitation of consumer choice and incentives to purchasing and, nevertheless, reject utilitarian arguments). Cf. Mark A. Lemley, The Modern Lanham Act and the Death of Common Sense 108 YALE L.J. 1687, 1694-1696 (1999); Ralph S. Brown, Advertising and the Public Interest: Legal Protection of Trade Symbols, 108 YALE L.J. 1619, 1622-1634 (1999); Rochelle Dreyfuss, We Are Symbols and Inhabit Symbols, so Should we be Paying Rent? Deconstructing the Lanham Act and Rights of Publicity, 20 COlumbia-VLA J. L. \& ARTS 123, 128 (1996). See also Mark A. Lemley \& Mark P. McKenna, Owning Mark(et)s 109 MiCH. L. REV. 137 (2010) (commenting on intuitive protection against free-riding as a species of unjust enrichment law).
} 
image to the extreme, ${ }^{54}$ without giving a sufficiently strong explanation of the need to protect brand image and offering an unbiased analysis of effects on competitors, consumers, and society as a whole. ${ }^{55}$ Instead, the CJEU simply focused on Dior's interest in the development of an aura of luxury and explained that:

[S]etting up a selective distribution system such as that at issue in the main proceedings which, according to the terms of the licence agreement between Dior and SIL, seeks to ensure that the goods are displayed in sales outlets in a manner that enhances their value, "especially as regards the positioning, advertising, packaging as well as business policy", contributes, as Copad acknowledges, to the reputation of the goods at issue and therefore to sustaining the aura of luxury surrounding them. ${ }^{56}$

This line of reasoning allowed the Court to conclude that the sale of Dior luxury goods to traders outside the selective distribution network might affect "the quality itself of those goods." $" 57$ Dior's contractual provision prohibiting sales to discount stores could thus be deemed to fall within the "ambit of operation" of Article 8(2) of the TMD and allow the invocation of trademark rights against SIL. The factors to be considered in this context are the nature of the luxury goods bearing the trademark, the volumes sold, whether the licensee sold the goods to discount stores that were not part of the selective distribution network regularly or only occasionally, the nature of the goods normally marketed by the discount stores, and the marketing methods normally used in that sector of activity. ${ }^{58}$

\section{Impact on Exhaustion of Rights}

With regard to further sales in the distribution chain, the CJEU addressed the exhaustion of Dior's trademark rights in cases of a licensee contravening the contractual prohibition to sell to discount stores. This question had to be answered in the light of Article 7(1) of the TMD, which sets forth Community-wide exhaustion preventing the trademark proprietor from prohibiting use of its trademark on goods that have been put on the internal market "by the proprietor or with his consent." Therefore, the question was whether "consent" in the sense of

\footnotetext{
${ }^{54}$ The CJEU made a similar statement already in Case C-337/95, Parfums Christian Dior SA and Parfums Christian Dior BV v. Evora BV, 1997 E.C.R. I-6013.

55 In this context, see Glenn Mitchell, Aura as Quality - A Sumptuary Law for Our Times?, 103 THE TRADEMARK REPORTER 1273, 1277 (2013) (arguing that the expansion of the concept of quality in Copad/Dior "does not serve the traditional source-identifying purposes of trademarks and the smooth and open functioning of markets. If anything, it serves to restrict markets, rendering otherwise legal transactions between a willing buyer and willing seller unlawful, as well as creating uncertainty in all transactions with licensees or other downstream sales. Moreover, Copad's holding is socially regressive. The prevailing social and economic systems of the last several centuries eschew formal class structure. While private parties may, by contract (and within certain limits), restrict distribution of goods, preservation of the social status quo should not constitute a cognizable trademark function.").

${ }^{56}$ Copad v. Dior, 2008 E.C.R. I-03421, ๆ 29.

${ }^{57}$ Id. \ 30.

${ }^{58} \mathrm{Id} \cdot \mathbf{9} 32$
} 
Article 7(1) of the TMD had to be determined based on the exhaustive list in Article 8(2) of the TMD. ${ }^{59}$

In this context, the Court first confirmed the general rule that, for the purposes of the exhaustion rule laid down in Article 7(1) of the TMD, a licensee putting trademarked goods on the market was considered to be acting with the consent of the trademark proprietor. ${ }^{60}$ However, as Article 8(2) TMD expressly enabled the trademark proprietor to invoke trademark rights against a licensee contravening certain provisions in the licence agreement, this general assumption of consent did not apply in cases falling under Article 8(2) of the TMD. The licensee's contravention of one of the clauses listed in Article 8(2) of the TMD thus precludes exhaustion of the rights conferred by the trademark for the purposes of Article 7(1) of the TMD. ${ }^{61}$

As the Court had already declared the list of relevant clauses in Article 8(2) of the TMD to be exhaustive and closed, the establishment of this link between Article 8(2) of the TMD and Article 7(1) of the TMD created a hierarchy of contractual stipulations: a breach of clauses falling under one of the five categories listed in Article 8(2) of the TMD leaves trademark rights intact, whereas exhaustion takes place when the contravention concerns clauses falling outside the scope of Article 8(2) of the TMD. In this latter case, the trademark proprietor may still have the chance of opposing the further commercialization of goods marketed in contravention of the licensing agreement. According to Article 7(2) of the TMD, this is possible when the trademark proprietor has legitimate reasons to oppose the further commercialization, especially where the condition of the goods is changed or impaired after they have been put on the market. In Copad/Dior, the CJEU explained with regard to this "last resort" that a balance had to be struck between the trademark proprietor's legitimate interest in a discount store not forming part of its selective distribution network and the discount store's legitimate interest in being able to resell the luxury goods using customary trade methods. ${ }^{62}$ With regard to the balancing of these interests, the Court had already held in Dior/Evora that:

[T]he fact that a reseller, who habitually markets articles of the same kind but not necessarily of the same quality, uses for trade-marked goods the modes of advertising which are customary in his trade sector, even if they are not the same as those used by the trade mark owner himself or by his approved retailers, does not constitute a legitimate reason, within the meaning of Article 7(2) of the Directive, allowing the owner to oppose that advertising, unless it is established that, given the specific circumstances of the case, the use of the trade mark in the reseller's advertising seriously damages the reputation of the trade mark. $^{63}$

\footnotetext{
${ }^{59} I d$. ๆๆ $38-39$.

${ }^{60} I d$. 46.

${ }^{61} I d .9 \uparrow 49-50$.

${ }^{62} I d .956$.

${ }^{63}$ Case C-337/95, Parfums Christian Dior SA and Parfums Christian Dior BV v. Evora BV, 1997 E.C.R. I-6013 I 46.
} 
In this vein, the CJEU deemed it decisive in Copad/Dior whether further discount store commercialization of trademarked luxury goods, using methods which are customary in its sector of trade, damages the reputation of the prestigious Dior trademark. ${ }^{64}$ If it does, the trademark proprietor had reason to oppose the further commercialization of goods in the sense of Article 7(2) of the TMD and the exhaustion rule of Article 7(1) of the TMD would not apply.

In sum, the decision thus offered Dior two options of neutralizing the exhaustion rule: it could argue first that the sale outside the selective distribution network affected the quality of the luxury goods itself in the sense of Article 8(2) of the TMD (no consent in the sense of Article 7(1) of the TMD); second, it could seek to show that the sale outside the selective distribution network damaged the reputation of the luxury trademark (consent in the sense of Article 7(1) of the TMD, but legitimate reason to oppose further commercialization by virtue of Article $7(2)$ of the TMD).

\section{Open Questions}

While this solution may seem dogmatically sound as long as the analysis is restricted to Articles 7 and 8 of the TMD, it raises doubts when further provisions are taken into account. Article 5(1) of the TMD defines the exclusive right enjoyed by the trademark proprietor as the entitlement "to prevent all third parties not having his consent from using [a conflicting sign] in the course of trade." Article 5(2) of the TMD adds the option of providing protection against dilution. Article 5(3) of the TMD makes it clear that the right to prohibit use (and, thus, the freedom to give consent), inter alia, covers offering goods under a conflicting sign, putting them on the market, or stocking them for these purposes without indicating any confinement to the parameters listed in Article 8(2) of the TMD. Considering this broad description of the scope of exclusive trademark rights in the EU, the CJEU pointed out in Copad/Dior that:

[C]onsent, which is tantamount to the proprietor's renunciation of his exclusive right within the meaning of Article 5, constitutes the decisive factor in the extinction of that right and must, therefore, be so expressed that an intention to renounce that right is unequivocally demonstrated. Such intention will normally be gathered from an express statement of consent. ${ }^{65}$

The Court went on to explain that, in the case of a licensee, consent could normally be assumed because of the economic link with the trademark proprietor. In this context, the Court attached particular importance to the licensing agreement offering the trademark proprietor the possibility of control over the activities of the licensee. Given this possibility of control, the Court was satisfied that in the case of use by a licensee, the trademark was still able to fulfil its essential function, namely "to offer a guarantee that all the goods bearing it

\footnotetext{
${ }^{64}$ Copad v. Dior, 2008 E.C.R. I-03421, $₫ 57$.

${ }^{65} \mathrm{Id}$. $\mid 42$.
} 
have been manufactured under the control of a single undertaking which is responsible for their quality." 66

In light of this description of the crucial role of the licensing agreement in safeguarding the appropriate functioning of the trademark, it is surprising that the CJEU finally arrives at the conclusion in Copad/Dior that consent in the sense of the exhaustion rule of Article 7(1) of the TMD is only absent in the case of clauses falling under one of the categories listed in Article $8(2)$ of the TMD. If the licensing agreement is central to ensuring sufficient "control of a single undertaking," it is conceivable to leave the definition of an appropriate standard of control to the trademark proprietor. In line with the broad rights found in Articles 5(1), (2) and (3) of the TMD, the trademark proprietor would then be free to make his consent dependent on those contractual obligations which he considers necessary to ensure "control of a single undertaking," not only in the sense of contractual liability, but also for the purpose of reserving the possibility to invoke trademark rights against the licensee. As Advocate General Kokott mentioned in her opinion in Copad/Dior:

One might assume that, where the licensee uses the trade mark in a manner that contravenes the licence agreement, the licensor is entitled to enforce his trade mark rights without restriction. ${ }^{67}$

Against this background, appropriate "control of a single undertaking" (i.e. control that renders the licensing agreement capable of securing the proper functioning of the trademark) could thus be understood to mean control in accordance with the standards set by the trademark proprietor himself and not by the closed list of Article 8(2) of the TMD. This seems plausible at least with regard to the relationship between the trademark proprietor and the licensee who has signed the licensing agreement and is fully aware of all conditions relating to the use of the trademark.

In sum, the assumption that the list in Article 8(2) of the TMD is exhaustive, thus, raises doubts in at least two respects. First, it implies the risk of an artificially broad interpretation of the listed categories, such as an interpretation of "the quality of the goods manufactured" in the sense of Article 8(2)(e) of the TMD covering not only material characteristics, but also "allure and prestigious image." 68 Second, it seems counterintuitive to make inroads into the broad scope of Article 5 of the TMD by restricting this general concept to cases falling under one of the categories of Article 8(2) of the TMD when it comes to the question of enforcing contractual stipulations in a licensing agreement. ${ }^{69}$

Given these open questions, it makes sense to explore alternative approaches to the list in Article $8(2)$ of the TMD and its impact on the exhaustion of rights. For an alternative approach to be convincing, it would have to eliminate the doubts about the assumption of a closed list in Article 8(2) of the TMD and offer an appropriate balance between the interests

\footnotetext{
${ }^{66} I d$. 45 .

${ }^{67}$ Opinion of Advocate General Kokott, Copad v. Dior, 2008 E.C.R. I-03421, ๆ 16.

${ }^{68}$ Copad v. Dior, 2008 E.C.R. I-03421 924.

${ }^{69} \mathrm{Id} .950$
} 
of the trademark proprietor (Dior), the licensee (SIL), the third party trader outside the selective distribution network (Copad), and the public at large. Hence, a comprehensive reconciliation of interests is required.

\section{Rights Against the Licensee}

As to the relationship between the trademark proprietor (Dior) and the licensee (SIL), the licensing agreement must be seen as the core instrument for the trademark proprietor to exert control over the activities of the licensee and ensure a consistent use and presentation of the trademark. ${ }^{70}$ Given this central role of the licensing agreement, it makes sense to let the broad description of exclusive rights in Articles 5(1), (2) and (3) of the TMD prevail over the closed list in Article 8(2) of the TMD. The trademark proprietor should be able to invoke trademark rights against the licensee not only with regard to contractual stipulations covered by Article $8(2)$ of the TMD, but also with regard to other conditions relevant to the use and presentation of the trademark in the broad sense of Articles 5(1), (2) and (3) of the TMD.

In this regard, the counterarguments on which the CJEU relied in Copad/Dior do not pose an insurmountable hurdle. As explained above, the CJEU arrived at the conclusion of a closed list in Article 8(2) of the TMD because, in contrast to Article 7(2) of the TMD, the enumeration of five categories of relevant contractual terms in Article 8(2) of the TMD contains no expression, such as "especially" or "in particular", which is normally used to indicate that the list has a merely illustrative character. ${ }^{71}$ However, this argument based on the wording of Article 8(2) of the TMD disregards the broader context in which the provision is placed.

First, it is unclear why the CJEU viewed Article 8(2) of the TMD exclusively through the prism of Article 7(2) of the TMD. Given the direct link between the grant of a license and the scope of exclusive rights, it would have been more consistent to focus on Articles 5(1), (2) and (3) of the TMD instead. These provisions delineate the exclusivity enjoyed by the trademark proprietor and thus, the room for licensing. Obviously, the categories listed in Article 8(2) of the TMD are narrower than the scope of rights granted in Article 5 of the TMD. Besides duration, form of use, scope of goods and services, territory, and quality, the broad definition of exclusive rights in Articles 5(1), (2) and (3) of the TMD covers further parameters, such as the quantity of goods and the reputation of the trademark. ${ }^{72}$ A systematic interpretation including Articles 5(1), (2) and (3) of the TMD thus does not support the assumption that the list in Article 8(2) of the TMD is exhaustive.

Second, it must not be overlooked that Article 8 of the TMD is only a rudimentary regulation of trademark licensing. Obviously, this single provision does not constitute a complete legal system for the reconciliation of the interests of trademark licensors and licensees. Against this background, it is not advisable to understand Article 8(2) of the TMD as the "final word" on

\footnotetext{
${ }^{70} I d . \uparrow 45$.

${ }^{71} I d$. $₫ 117-20$.

${ }^{72}$ See Opinion of Advocate General Kokott, Copad v. Dior, 2008 E.C.R. I-03421, ๆ 19-20 (discussing quantity as a relevant impact factor).
} 
situations in which the licensor may invoke trademark rights against the licensee. By contrast, the guarantee of freedom of contract must be factored into the equation. If the parties agree on further conditions defining the scope and reach of the license, this broader contractual framework should be accepted as a definition of the preconditions for safeguarding the functions of the trademark under the license in the sense of the jurisprudence of the CJEU. ${ }^{73}$ Accordingly, additional contractual obligations supplementing the provisions falling under Article $8(2)$ of the TMD should justify the invocation of trademark rights as well.

If the contracting parties agree on a specific standard of control governing the use and presentation of the trademark, this standard should determine the scope of trademark rights against the licensee, not the list in Article 8(2) of the TMD. By definition, the list is incapable of covering all impact factors that the contracting parties may find relevant to the consistent use and presentation of the trademark. The broadening of the room for invoking trademark rights against the licensee is also in the interest of consumers. As long as products bearing the trademark are put on the market by the trademark proprietor or an undertaking belonging to the trademark proprietor's selective distribution network, consumers will have an expectation of consistent use of the trademark, not only with regard to product quality, but also with regard to product presentation and brand image.

Practically speaking, the list in Article 8(2) of the TMD should not be regarded as a closed list in the relationship between the trademark proprietor and the licensee. Instead of limiting the room for invoking trademark rights to cases falling under the categories listed in Article 8(2) of the TMD, the trademark proprietor should be able to assert the rights granted and described in Articles 5(1), (2) and (3) of the TMD against the licensee with regard to all contraventions of the licensing agreement that have an impact on the proper functioning of the trademark in the marketplace.

Following this alternative approach, it is unnecessary to assume that "allure and prestigious image" form part of the "quality" of goods in the sense of Article 8(2)(e) of the TMD. ${ }^{74}$ By contrast, it is sufficient to hold that "allure and prestigious image" are relevant factors impacting the use and presentation of the trademark besides those factors listed in Article 8(2) of the TMD. They are relevant because the trademark proprietor has an interest in ensuring that the expectations of consumers dealing with a trader belonging to the selective distribution network are fulfilled. ${ }^{75}$ Hence, the trademark proprietor should be entitled to invoke trademark rights against the licensee on the basis of Articles 5(1), (2) and (3) of the TMD without the need to artificially expand the concept of "quality" in the sense of Article $8(2)(e)$

\footnotetext{
${ }^{73}$ Copad v. Dior, 2008 E.C.R. I-03421, $\mid 45$ (noting that it is established case law of the Court that the possibility of control following a licensing agreement should suffice for the trademark to be able to fulfil its functions. Considering this expectation of a safeguarding role of the licensing agreement, however, it seems consistent to leave the development of a more refined standard of control - going beyond the parameters listed in Article 8(2) of the TMD - to the parties).

${ }^{74} I d$ - 24.

${ }^{75}$ As to the guarantee of quality in cases of prestigious luxury trademarks, see Griffiths, supra note 53, at 635637.
} 
of the TMD. ${ }^{76}$ Such an interpretation safeguards the exclusive rights granted and described in Articles 5(1), (2) and (3) of the TMD when it comes to licensing. Under this alternative approach, Article 8(2) of the TMD would not be understood to set forth an exhaustive, closed list of contractual terms justifying the invocation of trademark rights against the licensee in case of contravention. Instead, Article 8(2) of the TMD would be seen as a provision with a declaratory nature. ${ }^{77}$ In any case, the trademark proprietor can assert trademark rights against a licensee who breaches a clause of the licensing agreement falling under one of the categories listed in Article 8(2) of the TMD. However, other contractual provisions concerning the proper functioning of the trademark can serve as a basis for a trademark claim as well. If the parties add further conditions of use to safeguard the proper functioning of the trademark under the licensing agreement, a breach of these additional conditions also justifies the invocation of trademark rights against the licensee. This approach underlines the central role of the licensing agreement in safeguarding the functions of the trademark, as described by the CJEU in Copad/Dior. ${ }^{78}$

Considering the safeguarding role of the licensing agreement, it is consistent to leave the development of a more refined standard of control - going beyond the parameters listed in Article $8(2)$ of the TMD - to the contracting parties and allow a trademark action in all cases where the proper functioning of the trademark is at stake. This alternative approach supports the assertion of trademark rights not only with regard to the control aspects listed in Article $8(2)$ of the TMD but also in other cases where the trademark proprietor legitimately seeks to secure the proper functioning of the trademark. ${ }^{79}$ Indications for such additional cases can be derived from CJEU jurisprudence. In L'Oréal/Bellure, the CJEU broadened the range of trademark functions enjoying protection under EU law by holding that:

[T]hese functions include not only the essential function of the trade mark, which is to guarantee to consumers the origin of the goods or services, but also its other functions, in particular that of guaranteeing the quality of the goods or services in question and those of communication, investment or advertising. ${ }^{80}$

Given this extension of the range of protected functions to communication, investment, and advertising, ${ }^{81}$ the prohibition of sales to discount stores in the licensing agreement between

\footnotetext{
${ }^{76}$ In this sense also Jochen Bühling, Die Markenlizenz im Rechtsverkehr, 1998 GEWERBLICHER RECHTSSCHUTZ UND URHEBERRECHT 196, 198 (1998) (arguing that, in case of contraventions of contractual provisions falling outside Article 8(2) of the TMD, it can be assumed that the trademark proprietor can invoke his trademark rights anyway because the use is no longer covered by the license and the licensee, in consequence, has no defense against an infringement claim).

${ }^{77}$ Cf. id. at 198 .

${ }^{78}$ Copad v. Dior, 2008 E.C.R. I-03421, Ф9 44-45.

${ }^{79}$ But see Mitchell, supra note 55, at 1276-1277 (arguing that the intention to preserve an aura of luxury through the restriction of sales to approved retailers in a selective distribution network is socially regressive because it upholds formal class structures and, in consequence, cannot be qualified as a legitimate trademark function anyway). For an in-depth analysis of this aspect of intellectual property protection, see Barton Beebe, Intellectual Property Law and the Sumptuary Code, 123 HARV. L. REV. 809 (2010).

${ }^{80}$ Case C-487/07, L’Oreal SA, et al v. Bellure et all, 2009 E.C.R. I-05185, ๆ 58.

${ }^{81}$ For a positive assessment of this development, see Haochen Sun, Reforming Anti-Dilution Protection in the Globalization of Luxury Brands, 45 GEO. J. INT’L L. 783, 794-795 (2014); Griffiths, supra note 55, at 635-637;
} 
Dior and SIL can be qualified as an additional legitimate aspect of control not mentioned in Article 8(2) of the TMD: to safeguard the proper functioning of the trademark under the licensing agreement, including the preservation of the prestigious brand image being the result of Dior's trademark-based communication, investment and advertising, Dior legitimately ${ }^{82}$ insisted on an enhanced standard of control in its relationship with SIL, including the prohibition of sales to discount stores. ${ }^{83}$ As the clause supports the proper functioning of the trademark in the sense of L'Oréal/Bellure, it is consistent to allow the invocation of trademark rights against a licensee selling to discount stores even though a prohibition of sales outside a selective distribution network is not listed in Article 8(2) of the TMD. Following this alternative approach, an artificial extension of the concept of "quality of the goods manufactured" in Article 8(2) of the TMD to "allure and prestigious image" can thus be avoided without restricting trademark rights against a licensee.

\section{Rights Against Outside Traders}

The balancing of interests is different with respect to the relationship between the trademark proprietor (Dior) and a trader outside the selective distribution network (Copad). For the trader outside the distribution network, the list in Article 8(2) of the TMD can be an important source of legal certainty. It limits the exposure to "downstream" distribution restrictions that may be set in the licensing agreement. In line with the Copad/Dior decision, the assumption of the list in Article 8(2) of the TMD being closed implies that "consent" in the sense of the exhaustion of rights under Article 7(1) of the TMD is only absent in the case of

Roncaglia \& Sironi, supra note 16, at 183-184; Machnicka, supra note 52, at 138-139. For more critical comments, see Arpan Banerjee, Non-Origin Infringement - Has Trade Mark Law Gone Too Far?, 43 INT'L REV. InTEll. Prop. \& COMP. L. 555 (2012); Martin R.F. Senftleben, Trade Mark Protection - A Black Hole in the Intellectual Property Galaxy?, 42 InT’L ReV. InTELl. Prop. \& CoMP. L. 383 (2011); Annette Kur, Lionel Bently, Ansgar Ohly, Sweet Smells and a Sour Taste - the ECJ's L'Oréal Decision (Max Planck Institute for Intellectual Property, Competition and Tax Law Research Paper Series No. 09-12, 2009) available at $\mathrm{http}: / / \mathrm{ssrn} . \mathrm{com} / \mathrm{abstract}=1492032$. As to problems arising from the continuous expansion of the protection of branding efforts and goodwill functions in trademark law, see Martin R.F. Senftleben, Adapting EU Trademark Law to New Technologies - Back to Basics?, in CONSTRUCTING EUROPEAN InTELlECTUAL PROPERTY: ACHIEVEMENTS AND NEW PERSPECTIVES 137 (Christophe Geiger ed., 2011); TRADE MARKS AND BRANDS - AN INTERDISCIPLINARY CRITIQUE (Lionel Bently, Jennifer Davis, \& Jane C. Ginsburg eds., 2008); Graeme B. Dinwoodie \& Mark D. Janis, Dilution's (Still) Uncertain Future, 105 MICH. L. REV. FIRST IMPRESSIONS 98 (2006); Barton Beebe, Search and Persuasion in Trademark Law, 103 MicH. L. REV. 2020 (2005); Mathias Strasser, The Rational Basis of Trademark Protection Revisited: Putting the Dilution Doctrine into Context, 10 Fordham InTELL. PROP. MEDIA \& ENT. L. J. 375 (2000).

${ }^{82}$ This conclusion seems in line with the interpretation of goodwill functions by the CJEU. In Joined Cases C236, 237, \& 238/08, Google France and Google et al. v. Louis Vuitton et al., 2010 E.C.R. I-02417, 9 91, the Court explained in respect of the advertising function that the trademark owner may have not only the objective of indicating the origin of its goods or services, "but also that of using its mark for advertising purposes designed to inform and persuade consumers." Id. In Case C-323/09, Interflora Inc. and Interflora British Unit v. Marks \& Spencer plc and Flowers Direct Online Ltd., 2011 E.C.R. I-08625, 9 60, the Court elaborated with regard to the investment function that in addition to its origin and (potential) advertising function, a trademark may also be used "to acquire or preserve a reputation capable of attracting consumers and retaining their loyalty." Id. See also Machnicka, supra note 52, at 142-143, with regard to the legitimacy of preserving the fragile aura of luxury of certain goods.

${ }^{83}$ This must not be misunderstood to mean that in the absence of a licensing agreement, the same standard of control should apply. By contrast, the legitimate interest of the discount store in being able to resell the goods in question by using advertising methods which are customary in his sector of trade, must be factored into the equation as well. See Case C-337/95, Dior v. Evora, 1997 E.C.R. I-6013, 944. 
contraventions falling under Article 8(2) of the TMD. When the list in Article 8(2) of the TMD is seen as an exhaustive enumeration in the context of the exhaustion provisions, the outside trader can thus rely on consent and the exhaustion of rights in all cases that are not covered by Article 8(2) of the TMD. The trademark proprietor, then, can only use the remaining option to oppose the resale based on the argument that he has a legitimate reason in the sense of Article 7(2) of the TMD. ${ }^{84}$ As the Court explained in Dior/Evora, this means freedom for the outside trader to use modes of advertising which are customary in his trade sector, even if they are not the same as those used by the trademark owner himself or by his approved retailers. ${ }^{85}$ In the context of trademark rights exhaustion, the assumption of the list in Article 8(2) of the TMD being closed would have the effect of preserving the freedom offered to resellers in Dior/Evora when the contractual prohibition to sell to traders outside a selective distribution network falls outside the scope of Article 8(2) of the TMD. ${ }^{86}$

This outcome does not place an unreasonably heavy burden on the trademark proprietor even if it is assumed that "allure and prestigious image" does not form part of the "quality" of goods. Article 8(2) of the TMD covers the duration of the contract, the form of use, the scope of the goods or services, the territorial scope of the license and the quality of the goods or services. Crucial contract parameters and, in particular, quality standards concerning the material characteristics of products are thus still covered by Article 8(2) of the TMD. The trademark proprietor would only lose the possibility of relying on Article 8(2) of the TMD and preventing the exhaustion of rights under Article 7(1) of the TMD with respect to contractual provisions prohibiting sales outside a selective distribution network. In line with the approach proposed above, this loss of trademark rights only applies to traders outside the selective distribution network. With regard to a licensee, the trademark proprietor keeps the option of bringing a trademark claim. In the internal relation with licensees, the trademark proprietor can draw on the full panoply of legal remedies and ensure compliance with contractual safeguards of a selective distribution system. This seems sufficient to ensure a functioning selective distribution network. ${ }^{87}$ It also seems adequate to impose the obligation on the trademark proprietor to ensure compliance with selective distribution standards within the group of approved retailers. Outsiders, by contrast, should be able to rely on sufficient internal control. When entering into a business relation with an approved retailer, an outside trader has a legitimate expectation of obtaining goods which he can further commercialize without having to fear that the trademark proprietor brings a trademark claim. In line with Dior/Evora, this legitimate expectation is only unjustified when the outside trader damages the trademark by using modes of advertising that fall short of customary advertising standards

\footnotetext{
${ }^{84}$ Rolf Sack, Die Erschöpfung von Markenrechten bei lizenzvertragswidrigem Vertrieb, GEWERBLICHER RECHTSSCHUTZ UND URHEBERRECHT INTERNATIONAL 198, 201 (2010) (criticizing the line of reasoning underlying the Copad/Dior decision, Sack arrives at a similar solution supporting the assumption of exhaustion on the basis of an analogous application of Articles 34 and 36 of the TFEU).

${ }^{85}$ Dior v. Evora, 1997 E.C.R. I-6013, $₫ 46$.

${ }^{86}$ In other words, the aim of the solution proposed here is to reinforce the beneficial role of the exhaustion doctrine vis-à-vis selective distribution networks. As to the importance of a proper ambit of operation of exhaustion in this context, see Irene Calboli, Reviewing the (Shrinking) Principle of Trademark Exhaustion in the European Union (Ten Years Later), 16 MARQ. INTELL. PROP. L. REV. 257, 276-278 (2012).

${ }^{87}$ However, see Andrew Griffiths, Trademarks and Responsible Capitalism, 43 INT'L REV. OF INTELL. PROP. \& COMP. L. 798, 819-820 (2012) (arguing in favour of broader control in line with the decision taken by the CJEU in Copad/Dior based on organisational behaviour).
} 
in his sector. In addition, the outside trader has no legitimate expectation of an entitlement to further commercialize trademarked goods when he acts in bad faith and seeks to profit from the breach of contractual provisions by an approved retailer. In this case, the trademark proprietor can invoke tort law against the outside trader.

Finally, the nuanced solution proposed here is likely to enhance consumer choice. When contractual terms concerning "allure and prestigious image" fall outside the scope of Article $8(2)$ of the TMD, the sale to discount stores in breach of the licensing agreement still allows the invocation of trademark rights against the licensee on the basis of the outlined alternative approach. However, this breach of the licensing agreement would not eliminate "consent" and the exhaustion of rights in the sense of Article 7(1) of the TMD. A trader outside a selective distribution network can thus legitimately resell trademarked luxury goods as long as he uses customary modes of advertising and does not damage the trademark himself. As a result, consumers have a broader choice: they can opt for the full brand experience - including the allure, prestigious image and aura of luxury offered by approved retailers inside the selective distribution network - and pay extra for this enhanced brand experience. However, consumers are also free to pay less and purchase the goods from an outside trader without experiencing an aura of luxury. ${ }^{88}$ In this latter case, the reference to quality standards in Article $8(2)(\mathrm{e})$ of the TMD still ensures that the material characteristics of the luxury goods comply with the standards inside the selective distribution network. In case of insufficient quality, no exhaustion takes place and the trademark proprietor can take action against the outside trader. ${ }^{89}$ The difference, thus, lies in the enhanced brand experience of an aura of luxury and the freedom of consumers to pay for this experience.

\section{A More Nuanced Approach}

In sum, it is thus advisable to adopt a more nuanced approach to the list of contractual terms in Article 8(2) of the TMD. In the relationship between the trademark proprietor and a licensee, this list should not be deemed exhaustive. By contrast, the trademark proprietor should be able to invoke trademark rights with regard to all contractual provisions concerning the proper functioning of the trademark, including communication, investment, and advertising functions. As a result, the trademark proprietor can enforce the prohibition of sales outside a selective distribution network without a need to artificially assume that "allure and prestigious image" form part of the "quality" of goods or services.

In the relationship between the trademark proprietor and an outside trader, however, the list in Article $8(2)$ of the TMD should be deemed closed and "allure and prestigious image" should be assumed to fall outside the scope of Article 8(2) of the TMD. This enhances the legal certainty for outside traders. It leads to a clear boundary line between internal and external relations. Within the circle of approved retailers, the trademark proprietor can draw on the full

\footnotetext{
${ }^{88}$ Cf. Mitchell, supra note 55, at 1276-1277, who highlights the additional aspect of avoiding the artificial maintenance or establishment of formal class structures.

${ }^{89}$ This is an important aspect of the nuanced approach recommended here. As to the importance of sufficient safeguards concerning product quality in case of trademark licenses, see Kur, supra note 9, at 5-6 and 8. As to the approach taken in the U.S., see Ann E. Doll, Trademark Licensing: Quality Control, 12 J. CONTEMP. LEGAL ISSUES 203 (2001).
} 
panoply of legal remedies to ensure compliance with a selective distribution network. In the external relation with outside traders, however, the trademark proprietor cannot prevent exhaustion as long as the material characteristics of products - the only relevant "quality" in the sense of Article 8(2) of the TMD under this alternative approach - are in line with the contractual standard and the outside trader uses customary modes of advertising and does not damage the trademark himself.

As a result, consumers have a broader choice. They can purchase luxury goods from an approved retailer and pay extra for the enhanced brand experience including an aura of luxury. Alternatively, they are free to buy from a trader outside the selective distribution network at a discount price while renouncing the enhanced brand experience of allure, prestige and luxury.

\section{Room for National Unfair Competition Law}

\section{The Case Martin Y Paz/Depuydt}

The jurisprudence of the CJEU in the area of trademark transactions also sheds light on problems concerning the relationship between harmonized EU law and national unfair competition law. In Martin Y Paz/Depuydt, a leather goods manufacturer had sold the company name "Nathan" to Martin Y Paz with regard to use for the production of a line of small leather goods, thereby guaranteeing the exclusive use of "Nathan" in the manufacturing and distribution of the small leather goods. However, the leather goods manufacturer retained "property in the name" with regard to the manufacture of handbags. The handbags business was later sold to David Depuydt together with the Benelux word mark NATHAN registered for leather items, clothing and shoes. To safeguard the guarantee of exclusivity given in the earlier contractual agreement with Martin Y Paz, the contract of the handbags business referred to the obligation not to manufacture or distribute small leather goods under the name "Nathan". 90

During several years of collaboration, Martin Y Paz and David Depuydt both used additional signs on their respective goods: a horizontally stretched letter $\mathrm{N}$ and the word sign "Nathan Baume." Martin Y Paz acquired Benelux trademark registrations of these two signs on leather items, clothing, and shoes, and added a stylized version of the word "Nathan". 91 With relations between the two companies becoming increasingly deteriorated, David Depuydt finally sought to have the Martin Y Paz trademark portfolio - consisting of the letter N, the stylized version of "Nathan" and the mark NATHAN BAUME - declared invalid or, at least, limited to small leather goods. When this invalidation action was dismissed, Martin Y Paz

\footnotetext{
${ }^{90}$ Case C-661/11, Martin Y Paz Diffusion SA v. David Depuydt and Fabriek van Maroquinerie Gauquie NV, OfFicial Website OF THE COURT OF JUSTICE OF THE EUROPEAN UNION , http://http://curia.europa.eu/juris/liste.jsf?num=C-661/11, ๆๆ 10-15 (September 19, 2013).

${ }^{91}$ Id. ๆฯ 16-21.
} 
invoked its trademark right to prevent David Depuydt from using signs that were identical or similar to the marks N and NATHAN BAUME for leather items, clothing, and shoes. ${ }^{92}$

At the national level, this trademark claim was rejected on the ground that Martin Y Paz had always recognized that David Depuydt could use signs identical to the marks for handbags and shoes. The Court of Appeals of Brussels was convinced of "irrevocable consent" given by Martin Y Paz regarding David Depuydt's use of the marks N and NATHAN BAUME on handbags and shoes. ${ }^{93}$ Appealing against this judgment, Martin Y Paz argued that it was free to withdraw its consent unilaterally at any time, and that a trademark claim brought after such withdrawal was not abusive, but a legitimate exercise of trademark rights. As the Court of Appeals of Brussels had also obligated Martin Y Paz to refrain from the manufacture and marketing of handbags and shoes under the marks N and NATHAN BAUME, Martin Y Paz added that the judgment amounted to an unjustified deprivation of its exclusive trademark right in those goods. ${ }^{94}$

Against this background, the CJEU was asked three questions: whether a finding of irrevocable consent based on an indeterminate period of shared use could definitely prevent the proprietor of a registered mark from asserting its exclusive right against a third party, whether a national rule prohibiting wrongful and abusive use of a right could lead to a definitive ban on the exercise of exclusive trademark rights for part of the goods for which the trademark was registered, and whether the trademark proprietor could definitely be prohibited from recommencing the use of the mark for certain goods or services when this would amount to unfair competition because of free-riding on the publicity made by the third party and possible confusion of customers. ${ }^{95}$

Approaching these questions, the CJEU clarified first that Article 8 of the TMD - dealing with trademark licensing - was inapplicable because no contractual relationship could be found between the parties. ${ }^{96}$ Therefore, the case had to be resolved on the basis of the exclusive rights conferred under Article 5 of the TMD. The central question, then, was whether national standards concerning the abuse of rights and unfair competition could deprive the trademark proprietor of the possibility to assert its trademark rights against a third party and use the trademark itself in respect of goods or services identical to those of the third party.

\section{Mantra of Complete Harmonization}

Insisting on complete harmonization of the rules relating to the rights conferred by a trademark in Articles 5 to 7 of the TMD, the CJEU answered this question by stating that:

\footnotetext{
${ }^{92} I d .9 \uparrow 22-25$.

${ }^{93} I d$. $\uparrow \uparrow 29-30$.

${ }^{94}$ Id. $\uparrow$ ๆ $32-33$.

${ }^{95} I d$ ๆ 135.

${ }^{96}$ Id. $\Upsilon$ \ 48-49.
} 
[S]ave for the specific cases governed by Article 8 et seq. of that directive, a national court may not, in a dispute relating to the exercise of the exclusive right conferred by a trademark, limit that exclusive right in a manner which exceeds the limitations arising from Articles 5 to 7 of the directive. ${ }^{97}$

The Court added that none of the limitations laid down in Article 6 of the TMD was relevant to the case. Exhaustion of trademark rights in the sense of Article 7 of the TMD could only play a role as long as Martin Y Paz had not withdrawn the consent given to David Depuydt. ${ }^{98}$ Inherent limits of the exclusive rights granted in Article 5 of the TMD which can be derived from the Court's "function theory", namely the limitation to use liable adversely to affect a protected trademark function, ${ }^{99}$ could only support a decision in favour of continued use by David Depuydt if no encroachment upon protected trademark functions could be found. Otherwise, the decision to deprive Martin Y Paz of the possibility to exercise its exclusive right against David Depuydt would exceed the limitations arising from Articles 5 to 7 of the TMD. ${ }^{100}$ A finding of unlawful conduct in the light of national rules on abuse of rights and unfair competition could not justify an obligation to prolong shared use of registered marks. However, the national court was free to impose a penalty on the trademark proprietor or award damages because of unlawful withdrawal of consent. ${ }^{101}$

Instead of leaving room for national doctrines reflecting general principles of fairness and equity, such as abuse of right and the prohibition of unfair competition, the CJEU thus postulated the precedence of harmonized EU trademark law and the pre-emption of flexible national standards. On the one hand, this approach may seem consistent when the rules of harmonized EU trademark law are qualified as leges speciales vis-à-vis more general national standards. On the other hand, it is evident that the specific rules in the TMD are hardly capable of offering a sufficiently rich and balanced set of norms for an appropriate assessment of the wide variety of trademark transactions in practice. The error in the Court's line of

\footnotetext{
${ }^{97} I d .955$.

${ }^{98}$ Id. $\Upsilon$ ๆ $56-57$.

${ }^{99}$ As pointed out above, the trademark functions enjoying protection in EU law range from the traditional origin function to the goodwill functions of communication, investment, and advertising. See Case C-487/07, L'Oréal v. Bellure, 2009 E.C.R. I-05185, - 58. For a discussion of the role of the function theory in EU trademark law, see Annette Kur, Trademarks Function, Don't they?, 45 InT'L ReV. OF InTELL. ProP. \& ComP. L. 434 (2014); Martin R.F. Senftleben, Function Theory and International Exhaustion: Why it is Wise to Confine the Double Identity Rule in EU Trademark Law to Cases Affecting the Origin Function, EUR. INTELL. PrOP. REV. 2014, 518; Tobias Cohen Jehoram, The Function Theory in European Trade Mark Law and the Holistic Approach of the CJEU, 102 TRADEMARK REP. 1243 (2012). As to the traditional focus of CJEU jurisprudence on the origin function, see Case C-206/01, Arsenal Football Club plc v. Matthew Reed, 2002 E.C.R. I-10273, I 51; Case C-245/02, Anheuser-Busch v. Budejovicky Budvar, 2004 E.C.R. I-10989, I 59; Case C-48/05, Adam Opel AG v. Autec AG, 2007 E.C.R. I-1017, ๆ 21. For commentary, see P.J. Yap, Essential Function of a Trademark: From BMW to O2, 31 Eur. InTELL. Prop. REV. 81, 86-87 (2009); Ilanah Simon Fhima, How Does "Essential Function” Doctrine Drive European Trademark Law?, 36 INT'L REV. OF INTELL. ProP. \& CoMP. L 4012005 ; YANN BASIRE, LES FONCTIONS DE LA MARQUE, ESSAI SUR LA COHERENCE DU REGIME JURIDIQUE D'UN SIGNE DISTINCTIF (2014).

${ }^{100}$ Case C-661/11, Martin Y Paz Diffusion SA v. David Depuydt and Fabriek van Maroquinerie Gauquie NV, OFFICIAL WEBSITE OF THE COURT OF JUSTICE OF THE EUROPEAN UNION , http://http://curia.europa.eu/juris/liste.jsf?num=C-661/11, ๆๆ 58-60 (September 19, 2013).

${ }^{101}$ Id. $\mathbf{} 61$.
} 
reasoning clearly comes to the fore when considering the proviso "save for the specific cases governed by Article 8 et seq. of that directive" 102 which precedes the mantra of complete harmonization through Articles 5 to 7 of the TMD in Martin Y Paz/Depuydt.

The specific rules provided in Articles 8 and 9 of the TMD are of a rudimentary nature. Article 8 of the TMD concerns licensing and is confined to a specific contractual relationship. Article 9 of the TMD concerns acquiescence of the proprietor of an earlier trademark in third party use of a conflicting subsequent trademark and is confined to the specific situation where both parties hold trademark rights. Against this background, the case Martin Y Paz/Depuydt shows the considerable gaps. As the case concerned consent instead of a license and the position of a defendant without trademark rights to the signs at issue, Articles 8 and 9 of the TMD offered no solution. ${ }^{103}$ This finding should have led to the conclusion that there were no specific, harmonized rules of EU law that could pre-empt the application of national standards relating to abuse of rights and unfair competition. ${ }^{104}$

While the CJEU might have been correct in positing that the scope of rights conferred under EU trademark law is completely harmonized as a result of Articles 5 to 7 of the TMD, the Court was incorrect in assuming that this harmonization of the scope also implied complete harmonization of related legal norms and doctrines that may impact the exercise of EU trademark rights, such as trademark transaction rules, abuse of rights, and unfair competition law. Instead of holding that the effect of Articles 5 to 7 of the TMD was "a complete harmonisation of the rules relating to the rights conferred by a trademark", ${ }^{105}$ the Court should have limited its ruling to the finding that Articles 5 to 7 of the TMD had the effect of harmonizing the scope of trademark rights while leaving intact not only "Article 8 et seq. of that directive" 106 but also national rules concerning the exercise of trademark rights.

\section{Function Theory Unsatisfactory}

The dilemma arising from the maximum harmonization approach taken by the CJEU clearly comes to the fore in the decision itself. Having precluded the application of flexible national doctrines, the Court was incapable of offering a satisfactory alternative source of equity and fairness in harmonized EU trademark law. In the absence of an open-ended "due cause" provision covering cases of use of an identical sign for identical goods - the double identity situation that had arisen in Martin Y Paz/Depuydt left no room for invoking a general "due

\footnotetext{
${ }^{102}$ Id. 955.

${ }^{103}$ As pointed out above, the CJEU itself, id. $₫ 48$, found that Article 8 of the TMD was irrelevant to the case.

${ }^{104}$ With regard to the state of law against unfair competition in the EU and the interplay between harmonized EU law and national regimes, see Frauke Henning-Bodewig, Die Bekämpfung unlauteren Wettbewerbs in den EUMitgliedstaaten: eine Bestandsaufnahme, GEWERBLICHER RECHTSSCHUTZ UND URHEBERRECHT INTERNATIONAL 2010, 273; Frauke Henning-Bodewig, Nationale Eigenständigkeit und europäische Vorgaben im Lauterkeitsrecht, GEWERBLICHER RECHTSSCHUTZ UND URHEBERRECHT INTERNATIONAL 2010, 549; LAUTERKEITSRECHT UND ACQUis COMMUNAUTAIRE, (Reto M. Hilty \& Frauke Henning-Bodewig eds., 2009); LaW Against Unfair Competition - Towards a New Paradigm In Europe?, (Reto M. Hilty \& Frauke Henning Bodewig eds., 2007).

${ }^{105}$ Id. $\mid 54$.

${ }^{106}$ Id. ๆ 55.
} 
cause" defence $-{ }^{107}$ the closed catalogue of limitations in Article 6 of the TMD did not offer sufficient room to factor into the equation abuse of rights and unfair free-riding by the trademark proprietor. ${ }^{108}$ Moreover, a solution based on the exhaustion of rights in accordance with Article 7 of the TMD was no longer available after the Court had abandoned the option of entitling the national court to declare the withdrawal of consent null and void because of an abuse of trademark rights and unfair competition. Once Martin Y Paz can lawfully withdraw its consent, the precondition of "consent" in the sense of Article 7(1) of the TMD is no longer fulfilled. ${ }^{109}$

The CJEU could thus not do more than recall, as a last resort, its vague function theory as an inherent limitation of the rights granted in Article 5(1)(a) of the TMD. ${ }^{110}$ According to this theory, use of a conflicting sign is not actionable in double identity situations as long as the use is not liable to adversely affect at least one of the trademark functions presently enjoying protection in EU trademark law. As explained above, the protected functions range from traditional origin and quality functions to the role of trademarks in communication, investment, and advertising. ${ }^{111}$ Attempts to define the protected functions, however, show that the CJEU has difficulty tracing their conceptual contours. In Google/Louis Vuitton, the Court explained in respect of the advertising function that the trademark owner may have not only the objective of indicating the origin of its goods or services, "but also that of using its mark for advertising purposes designed to inform and persuade consumers." ${ }^{112}$ In Interflora/Marks $\&$ Spencer, the Court elaborated on the investment function, explaining that in addition to its origin and (potential) advertising function, a trademark may also be used "to acquire or preserve a reputation capable of attracting consumers and retaining their loyalty." 113 This

\footnotetext{
107 See the double identity rule set forth in TMD, supra note 2, at art. 5(1)(a) on the one hand, and the antidilution provision in TMD, supra note 2, at art. 5(2) on the other. While Article 5(2) of the TMD includes a flexible defense of "due cause", a corresponding opening clause is sought in vain in Article 5(1)(a) of the TMD.

${ }^{108}$ For the debate on this shortcoming of the present limitation infrastructure in EU trademark law, see See RolAND KNAAK, ANNETTE KUR, \& ALEXANDER VON MÜHLENDAHL, supra note 12, at 9 2.266; Martin R.F. Senftleben, Overprotection and Protection Overlaps in Intellectual Property Law: The Need for Horizontal Fair Use Defences, in The Structure of Intellectual Property Law: Can One Size Fit All? 136 (Annette Kur and Vytautas Mizaras eds., 2011). As to the solutions found on the basis of the flexible "due cause" defense available under TMD, supra note 2, at art. 5(2), see Case C-65/12, Red Bull v. Bulldog, OfFICIAL WEBSITE OF THE COURT OF JUSTICE OF THE EUROPEAN UNION, available at http://curia.europa.eu/juris/liste.jsf? num $=C$ 65/12, I 46; Case C-323/09, Interflora et. al v. Marks \& Spencer et al., 2011 E.C.R. I-05185, I 91; Bundesgerichtshof [BGH] [Federal Court of Justice], March 11, 2008, Neue Juristische Wochenschrift [NJW] 2110, 2008 (Ger.).; Bundesgerichtshof [BGH] [Federal Court of Justice], Feb. 3 2005, Case I ZR 159/02, Lila Postkarte, Gewerblicher Rechtsschutz UND UrheberRecht 2005, 583; Cour de Cassation [Cass.] [French Supreme Court], April 8, 2008, Bull. 2008, Case 06-10961, Greenpeace v. Esso; Cour de Cassation [Cass.] [French Supreme Court], April 8, 2008, Bull. 2008, Case 07-11251, Greenpeace v.Areva; Court of Appeals of Amsterdam, Case LJN BS7825, Sept. 3, 2011, Mercis and Bruna v. Punt, - 4.1. Cf. Vincenzo Di Cataldo, The Trademark with a Reputation in EU Law - Some Remarks on the Negative Condition 'Without Due Cause', 42 INT'L REV. OF INTELL. PROP. \& COMP. L. 833 (2011).

${ }^{109}$ Case C-661/11, Martin Y Paz Diffusion SA v. David Depuydt and Fabriek van Maroquinerie Gauquie NV, OFFICIAL WEBSITE OF THE COURT OF JUSTICE OF THE EUROPEAN UNION , http://http://curia.europa.eu/juris/liste.jsf?num=C-661/11, \ 57 (September 19, 2013).

${ }^{110} I d$. 158 . For a discussion of the function theory in EU trademark law, see the references supra note 99.

${ }^{111}$ Case C-487/07, L’Oreal SA, et al v. Bellure et all, 2009 E.C.R. I-05185, 98.

112 Joined Cases C-236, 237, \& 238/08, Google France and Google et al. v. Louis Vuitton et al., 2010 E.C.R. I02417, ๆ 91 .

${ }^{113}$ Interflora v. Marks \& Spencer, 2011 E.C.R. I-05185, ๆ 60.
} 
investment function may overlap with the advertising function. Nonetheless, it had to be separated according to the Court because not only advertising was employed, but also "various commercial techniques" when the trademark was used to acquire or preserve a reputation. ${ }^{114}$

These vague indications of potential objectives underlying the use of trademarks for advertising and investment strategies hardly qualify as reliable clarifications of the scope and reach of the protection which these functions should enjoy in double identity cases. The fact that the CJEU also recognized a trademark's communication function further enhances the legal uncertainty surrounding the function theory. As the Court did not comment on the communication function in any subsequent decision, this function still constitutes terra incognita. However, in Martin Y Paz/Depuydt, as a result of the pre-emption of national rules on abuse of rights and unfair competition, this openness of the function theory appears as an advantage rather than a shortcoming. In fact, the explicit reference to the function theory in the decision ${ }^{115}$ can be understood as an indication that the CJEU is prepared to use the function theory itself as an alternative rule of equity and fairness to fill the gap resulting from the rejection of national law.

In fact, the Court has already used the function theory as a "meta norm" of fairness and equity capable of forcing specific infringement criteria in EU trademark law onto the "sidelines.","16 In line with this use of the function theory, a trademark infringement action cannot succeed without a showing of adverse effect on at least one protected function. In this vein, the Court openly conceded in Leidseplein Beheer/Red Bull that the function theory was a means of putting absolute protection under Article 5(1)(a) of the TMD "into perspective". "117 In Interflora/Marks \& Spencer, the Court saw the absence of a conflict with any protected trademark function as a relevant factor for determining if a trademark's unauthorized use for the purpose of informing consumers about alternative offers in the marketplace was made with "due cause" according to Article 5(2) of the TMD. ${ }^{118}$ Similarly, the Court pointed to the absence of a conflict with any protected trademark function as a reason for setting territorial limits to a prohibition against further infringement of a CTM in Chronopost/DHL. ${ }^{19}$

\footnotetext{
${ }^{114}$ Id. 961.

${ }^{115}$ Case C-661/11, Martin Y Paz Diffusion SA v. David Depuydt and Fabriek van Maroquinerie Gauquie NV, OFFICIAL WEBSITE OF THE COURT OF JUSTICE OF THE EUROPEAN UNION , http://http://curia.europa.eu/juris/liste.jsf?num=C-661/11, qه 58-60 (September 19, 2013).

${ }^{116}$ See also Kur, supra note 111 , at 443 , (seeing the function theory as a basis for introducing a more flexible infringement analysis including considerations of fair and reasonable competition into EU trade mark law).

117 Case C-65/12, Leidseplein Beheer v. Red Bull, OfFICIAL WeBsite of THE COURT Of JUSTICE OF THE EUROPEAN UNION, available at http://curia.europa.eu/juris/liste.jsf? num =C-65/12, ๆ 32 (2014).

118 Interflora v. Marks \& Spencer, 2011 E.C.R. I-05185, 9 91, (clarifying that "where the advertisement displayed on the internet on the basis of a keyword corresponding to a trade mark with a reputation puts forward - without offering a mere imitation of the goods or services of the proprietor of that trade mark, without causing dilution or tarnishment and without, moreover, adversely affecting the functions of the trade mark concernedan alternative to the goods or services of the proprietor of the trade mark with a reputation, it must be concluded that such use falls, as a rule, within the ambit of fair competition in the sector for the goods or services concerned and is thus not without "due cause" for the purposes of Article 5(2)." (emphasis added)).

${ }^{119}$ Case C-235/09, DHL Express France SAS v. Chronopost SA, 2011 E.C.R. I-02801, ๆๆ 46-48.
} 
Advocate General Kokott gave an impressive demonstration of the use of the function theory as a "meta norm" of fairness and equity in Viking Gas/Kosan Gas. Having concluded that the exhaustion doctrine could not be applied to the gas in the composite bottles at issue (an assumption which the Court did not adopt), Kokott embarked on an analysis of the refilling of gas bottles in light of the function theory. ${ }^{120}$ Addressing communication, investment and advertising functions, Kokott postulated that:

$[\mathrm{N}]$ ot every adverse affect on those functions justifies the application of [the double identity rule laid down in] Article 5(1) of Directive 89/104. The protection of those functions on the basis of that provision, first, must not undermine the requirements of specific protective rules and, second, must respect overriding other interests. ${ }^{121}$

The assessment of "overriding other interests", then, led the Advocate General to conclude that even though the exhaustion doctrine did not apply, consumers' property rights in the composite bottles and the need to protect competition outweighed the affected functions of the trademark and justified the limitation of trademark rights. If consumers could only exchange empty gas bottles with Kosan as an exclusive supplier, they would not be free to exercise their property rights in the bottles by becoming customers of other suppliers. In this latter regard, the situation was comparable to the provision of repair services for a particular make of car, which also fell under a limitation of trademark rights. ${ }^{122}$

\section{No Pre-Emption of National Doctrines}

Despite this remarkable potential to serve as a fairness and equity norm within EU trademark law, it remains unclear how the function theory could be a substitute for pre-empted national rules on abuse of right and unfair competition in Martin Y Paz/Depuydt. As Annette Kur pointed out, it is hard to see how the national court could avoid a finding of an adverse effect on the essential origin function in light of use of an identical sign in respect of identical goods. ${ }^{123}$ As a way out, it would have to be assumed that David Depuydt does not cause confusion when using the marks N and NATHAN BAUME for handbags and shoes because the public is accustomed to Depuydt's products offered under these marks.

This twisted line of argument, however, can hardly be reconciled with the CJEU's further consideration that Martin Y Paz should be free to withdraw its consent for shared use of the marks. Hence, the lack of harmonized EU rules on abuse of right and unfair competition cannot be corrected by applying the open-ended function theory instead. As long as EU trademark law does not provide for a sufficiently robust body of fairness and equity norms, the CJEU should refrain from the overambitious pre-emption of national doctrines that provide indispensable room to manoeuvre. As Annette Kur concludes:

\footnotetext{
${ }^{120}$ Case C-46/10, Viking Gas A/S v. Kosan Gas A/S, 2011 I-06161, ๆๆ 36-37.

${ }^{121} I d$. 959.

${ }^{122} I d$ ๆ $65-67$.

${ }^{123}$ Kur, supra note 111 , at $450-451$.
} 
[C]ases like Martin Y Paz therefore need a more comprehensive evaluation scheme which is equally based on overarching principles such as equity and fairness, but without being limited to the aspects on which the functions discussion is mainly focused. General principles informing such an evaluation (like "unclean hands"; or "Treu und Glauben") are found in practically every organically grown legal system. In contrast, European law, at least for now, does not represent a comprehensive, fully developed legal system providing for an overarching corpus of fundamental fairness principles... This particular situation calls for a cautious approach; it would be wise not to interfere more than absolutely necessary with national correction mechanisms. Unfortunately, the CJEU does not always muster the kind of self-restraint one might wish for in such situations. ${ }^{124}$

\section{E. Conclusion}

Despite the rudimentary nature of trademark transaction rules in harmonized EU trademark law, the CJEU follows a maximalist approach. In Copad/Dior, the Court declared the list of contractual provisions justifying the invocation of trademark rights against a licensee to be exhaustive and closed in EU law. In Martin Y Paz/Depuydt, the Court assumed that the harmonized rules relating to the rights conferred by a trademark pre-empted flexible national standards in the area of unfair competition law and abuse of rights. The results of this jurisprudence are unsatisfactory.

With the assumption of a closed list of contractual provisions justifying the invocation of trademark rights against a licensee, the Court created a "straightjacket" that requires an artificially-broad interpretation of the relevant categories of contractual terms, such as the inclusion of "allure and prestigious image" in the concept of "quality". Adopting a more nuanced approach based on the above analysis, the Court could arrive at a more convincing balancing of interests that ensures full control of the trademark proprietor over selective distribution rules within the circle of approved retailers, enhances legal certainty for traders outside the selective distribution network and offers consumers a broader choice.

With the pre-emption of flexible national unfair competition and abuse of right standards, the CJEU created a considerable gap in the regulation of trademark transactions. The Court's use of the requirement of adverse effect on at least one protected trademark function as a precondition for the successful invocation of trademark rights cannot easily fill this gap. As a result, traders operating on the basis of consent from the trademark owner are exposed to the substantial risk of trademark protection becoming excessive in the sense that it minimizes the impact of limiting national doctrines without offering an adequate alternative at the level of harmonized EU law.

Given these shortcomings, the CJEU should seize future opportunities to recalibrate the interpretation of EU trademark transactions law and establish a system that leaves room for a

${ }^{124} I d$. at 453 . 
more comprehensive consideration of all interests involved and a better interaction between harmonized EU rules and supplementary national fairness and equity norms. 